\title{
Penayangan Reka Ulang Adegan Kriminalitas Dalam Pandangan Penonton (Studi Kasus Rekonstruksi Trans7)
}

\author{
Susilowati $^{1}$, Devy Putri Kussanti ${ }^{2}$ \\ ${ }^{1}$ Universitas Bina Sarana Informatika, susilowati.ssi@bsi.ac.id \\ ${ }^{2}$ Universita Bina Sarana Informatika, devy.dpk@bsi.ac.id
}

\begin{abstract}
ABSTRAK
Pada awalnya kembali lagi hanya sebagai media pemberi informasi, tetapi televisi tidak cukup hanya menyuguhkan berita atau news saja. Kini media televisi juga berperan sebagai media edukasi, media dakwah, media bisnis, media belanja. Salah satu program televisi adalah program reka ulang adegan kriminalitas, yaitu menggambarkan kembali tempat kejadian perkara di beberapa stasiun televisi, membuat masyarakat mengetahui lebih detail dan lebih jelas tentang peristiwa dan adegan tindakan kriminal yang dilakukan oleh seseorang. Di antaranya adalah program "rekonstruksi" yang disiarkan oleh stasiun televisi Trans7, di mana siaran itu dikemas dalam bentuk drama dan menceritakan kronologi rinci kasus-kasus kriminal yang terjadi. Program tersebut menimbulkan berbagai pandangan masyarakat baik pro maupun kontra. Untuk itu, penulis melakukan penelitian metode penelitian dengan pendekatan kualitatif deskriptif, menggunakan metode observasi non-partisipan dan wawancara. Hasil penelitian ini adalah program " Rekonstruksi Trans7 " dapat dijadikan modus kejahatan karena modus kejahatan secara eksplisit / jelas digambarkan dalam setiap episodenya dan secara tidak langsung berdampak pada psikologis massa yang sangat luas, dikarenakan ditayangkan setiap hari dengan menampilkan beragam modus dari setiap kronologis yang diceritakan dan menayangkannya dengan nuansa yang mudah dipahami masyarakat, serta acara tersebut dapat digunakan sebagai acara yang memberikan pembelajaran kepada pemirsa tentang tingkat kesadaran masyarakat terhadap kejahatan
\end{abstract}

Kata Kunci : Media masa, televisi, program televisi, penonton

\section{ABSTRACT}

At first it returned only as a media providing information, but television was not enough to only offer news or news. Now television media also acts as a medium of education, media propaganda, business media, shopping media. One television program is a program to recreate the crime scene, which is to re-describe the scene of a crime on several television stations, making the public know more details and clearer about the events and scenes of criminal acts committed by someone. Among them is the "reconstruction" program which was broadcast by the Trans 7 television station, where the broadcast was packaged in the form of drama and told a detailed chronology of criminal cases that occurred. The program raises various views of the community both pro and contra. For this reason, the authors conducted research methods with a descriptive qualitative approach, using the method of non-participant observation and interviews. The result of this study is that the "Trans 7 Reconstruction" program can be used as a mode of crime because the crime mode is explicitly described in each episode and indirectly affects a very broad psychological mass, because it is aired every day by displaying various modes of chronology told and broadcast it with a nuance that is easily understood by the community, and the event can be used as an event that provides learning to viewers about the level of public awareness of crime. 
Keywords: Mass Media, Television, Television Programs and Audience:

\section{PENDAHULUAN}

Televisi yang notabenenya adalah sebagai salah satu media massa yang masih memiliki kekuatan dari segi banyaknya penonton dan menampilkan informasi secara menarik melalui audio visual sehingga masyarakat dapat dengan mudah dan cepat menangkap atau menerima informasi yang disiarkan, kini telah menghadapi banyak tantangan dengan adanya perubahan jaman yang semakin canggih dan pesat. Tidak hanya berfungsi sebagai media pemberi informasi dan hiburan, televisi kini juga berperan sebagai media edukasi, media dakwah, media bisnis, media belanja dan lain sebagainya. Dalam kaitannya sebagai media informasi dan edukasi, televisi melalui program atau content yang disediakan oleh stasiun televisi kini telah mengalami pengembangan dan pergeseran makna, dimana pada awalnya informasi yang diberikan hanya sebatas memberitahukan tetapi kemudian oleh khalayak atau masyarakat dimaknai dengan edukasi dan pembelajaran yang dapat mempengaruhi penontonnya . Jika konteks edukasi bersifat positif maka hal tersebut masih dapat dikatakan sebagai pembelajaran, hanya saja jika konteks edukasi bersifat negatif dan cenderung mempengaruhi maka hal tersebut dikatakan sebagai bencana.

Melalui program atau content yang disiarkan, stasiun televisi mulai berlomba-lomba untuk menarik minat penonton. Tak terkecuali dengan menyuguhkan content yang berbau kriminal. Pada awalnya kembali lagi hanya sebagai media pemberi informasi, tetapi televisi tidak cukup hanya menyuguhkan berita atau news saja. Kini maraknya program reka ulang adegan kriminalitas di beberapa stasiun televisi, membuat masyarakat mengetahui lebih detail dan jelas mengenai kejadian maupun adegan dari tindakan kriminalitas yang telah dilakukan oleh seseorang.

Pada awalnya penayangan reka ulang adegan kriminalitas atau rekonstruksi hanyalah menyiarkan di area Tempat Kejadian Perkara atau TKP oleh pihak Kepolisian dan pada saat kejadian gelar perkara ini pun banyak masyarakat disekeliling TKP berusaha untuk melihatnya. Hal ini dianggap sebagai kegiatan yang menarik oleh beberapa stasiun televisi dan dianggap dapat memuaskan penonton apabila ditayangkan ulang dengan reka adegan atau disimulasikan kronologis kejadian secara audio visual sehingga dapat dilihat secara jelas dan lengkap.

Adalah program Rekonstruksi yang disiarkan di Trans7 setiap hari pada pukul 21.30-23.00, merupakan salah satu dari program televisi dengan menyiarkan reka ulang adegan kriminalitas yang dijadikan drama ilustrasi.

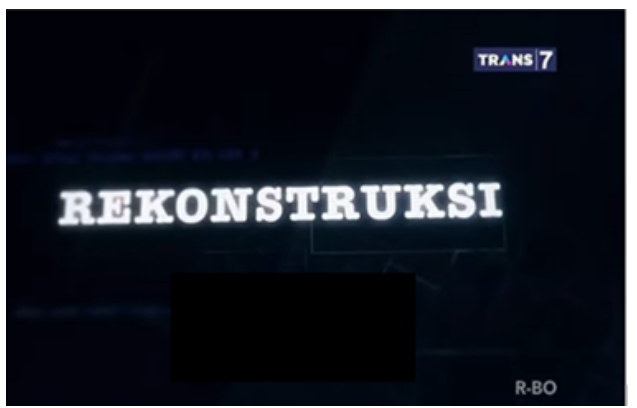

Gambar 1. Program Rekonstruksi Trans7 Sumber : (“TRANS7 | Rekonstruksi," n.d.)
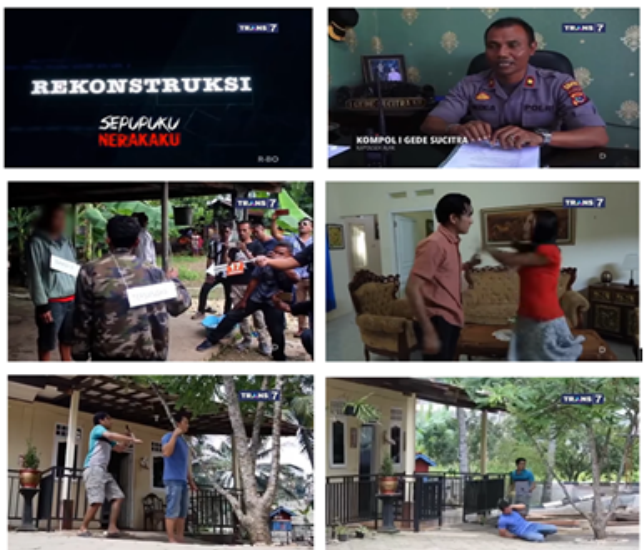

Sumber: (Rote, 2019)

Gambar 2. Salah satu episode pada program acara Rekonstruksi Trans7, "Sepupuku Nerakaku" tayang 25 Januari 2019

Dimana di dalam acara program tersebut, ditayangkan bagaimana kasus pembunuhan yang terjadi di NTT, yaitu pembunuhan seorang laki-laki yang telah berselingkuh dengan saudara iparnya atau istri dari si pelaku pembunuhan. Dalam siaran tersebut ditayangkan bagaimana proses atau kronoligis kejadian, bahkan divisualisasikan dengan 
adegan drama dari awal perselingkuhan hingga akhir terjadinya pembunuhan terjadi. Di dalamnya terdapat adegan-adegan yang seharusnya tidak divisualisasikan seperti halnya pada saat penikaman pelaku kepada korban dan juga adegan korban berselingkuh dengan istri pelaku, serta adegan pemukulan pelaku dengan istrinya.

Bila melihat salah satu program Rekonstruksi tersebut diatas yang merupakan salah satu contoh dari beberapa episode lainnya, seperti pembunuhan satu keluarga yang terjadi di Bekasi yang terjadi pada tanggal 13 November 2018. Sehingga perlunya pandangan dari masyarakat atas program tersebut.

Berdasarkan uraian diatas, maka permasalahan pokok pada penelitian ini adalah Bagaimana Penayangan Reka Ulang Adegan Kriminalitas Dalam Pandangan Masyarakat (Studi Kasus Program Rekonstruksi Trans7).

Tujuan dari penelitian ini adalah untuk mengetahui Pandangan masyarakat terhadap penanyangan reka ulang adegan kriminalitas khususnya pada program "Rekonstruksi Trans7".

\section{KAJIAN LITERATUR}

Pada penelitian ini didukung oleh beberapa teori, yaitu :

\section{Media massa}

Media massa menurut Cangara adalah "alat yang digunakan dalam penyampaian pesan dari sumber kepada khalayak (menerima) dengan menggunakan alat komunikasi mekanis seperti surat kabar, film, radio dan TV”. (Supriana, 2017)

Sedangkan Quail menyatakan bahwa media massa merupakan sumber kekuatan alat kontrol, manajemen, dan inovasi dalam masyarakat yang dapat didayagunakan sebagai pengganti kekuatan atau sumber daya lainnya. Media juga dapat menjadi sumber dominan yang dikonsumsi oleh masyarakat untuk memperoleh gambaran dan citra realitas sosial baik secara individu maupun kolektif, dimana media menyajikan nilai-nilai dan penilaian normatif yang dibaurkan dengan berita dan hiburan. (Supriana, 2017)
Straubhaar menyatakan bahwa media massa mempunyai peran yang penting dalam memberikan pengaruh bagi keputusan yang berkaitan dengan kepentingan publik. Media juga mampu memunculkan isu yang baru yang bisa mempengaruhi berbagai kebijakan pemerintah, misalnya demonstrasi menolak kenaikan harga bahan bakar minyak. Maka, kebijakan media dalam mengatur agendanya, secara tidak langsung akan berdampak pula pada kebijakan pemerintah yang berkaitan dengan hidup masyarakat.(Esti \& Hartanti, 2015)

Menurut Nugroho; Kebijakan media sebagai kebijakan publik harus tetap mengutamakan dan memberikan ruang bagi publik untuk menyuarakan aspirasinya atau disebut juga mediasphere. Maka, tidak akan ada lagi pembiaran suara rakyat dan ketidakberpihakan terhadap rakyat. Namun, rakyat akan semakin diutamakan kepentingannya dengan kebebasannya dalam berpendapat atau freedom of speech di media. Namun, dari sisi perkembangan sektor industri media, tidak lepas dari yang namanya perkembangan teknologi, dinamika pasar, dan kekuasaan para pemilik media.(Esti \& Hartanti, 2015)

\section{Karakteristik Media televisi}

Karakteristik dari media televisi menurut Wahyudi dalam Cangara adalah dapat didengar dan dilihat bila ada siaran, dapat dilihat dan didengar kembali, bila diputar kembali, daya rangsang sangat tinggi, elektris, sangat mahal, daya jangkau besar.(Morisan, 2010)

Karakteristik televisi yang membuatnya banyak menyita perhatian banyak orang dikarenakan kelebihan utama televisi yang menyatukan antara fungsi audio dan visual, disertai dengan kemampuan dalam memainkan berbagai warna.(Ferry, 2014)

Sedangkan Effendy menyebutkan mengenai sejumlah fungsi pers atau media massa di dalam masyarakat. Menurutnya fungsi pers di dalam masyarakat adalah sebagai berikut ini: a) fungsi menyiarkan informasi (to inform), b) fungsi mendidik (to educate), c) fungsi menghibur (to entertain), dan d) fungsi mempengaruhi (to influence).(Ferry, 2014)

\section{Reka Ulang atau Rekonstruksi}


Sedangkan Reka Ulang atau Rekonstruksi mempunyai arti sebagai penyusunan (penggambaran) kembali.(aparti.com, 2019)

Sehingga bila dihubungkan dengan kriminalitas, maka dapat dimaksudkan adalah penyusunan atau penggambaran kembali suatu kronologis dalam kriminalitas.

Pada Pedoman Perilaku Penyiaran yang dibuat oleh Komisi Penyiaran telah diatur beberapa peraturan mengenai siaran dalam bentuk rekonstruksi, yaitu Ketika lembaga penyiaran harus menyajikan berita atau dokumenter yang didasarkan pada reka ulang (rekonstruksi) dari peristiwa yang sesungguhnya terjadi, rekonstruksi tersebut harus disampaikan dengan :

1. Menjelaskan kepada khalayak sejaumana kesesuaian dan kekuatan materi dengan peristiwa sebenarnya apakah dibuat berdasarkan interpretasi bebas tentanv peristiwa yang terjadi atau setiap detail penggambaran yang ditampilkan benarbenar akurat atau persis dengan peristiwa aslinya.

2. Tidak boleh ada perubahan atau penyimpangan terhadap fakta yang dapat menimbulkan intreprestasi yang salah atau tidak adil terhadap pihak yang memiliki kepentingan langsung terhadap isi program.

3. Lembaga penyiaran harus memberitahukan dengan jelas asal versi reka ulang atau ilustrasi tersebut. Satsiun televisi dapat mencantumkan di layar, dan stasiun radio dapat melakukannya dengan memberitahu di awal, atau akhir program.

4. Lembaga penyiaran tidak boleh merugikan pihak-pihak yang menjadi subjek dan objek reka ulang.(KPI, 2012)

Bahkan didalam Pedoman Perilaku Penyiaran pun telah diatur tentang penyiaran Rekonstruksi kejahatan, yaitu;

1. Adegan rekonstruksi kejahatan yang eksplisit dan rinci tidak boleh disiarkan

2. Adegan rekonstruksi kejahatan seksual dan pemerkosaan sama sekali tidak boleh disiarkan.

3. Siaran rekonstruksi kejahatan harus memperoleh ijin dari korban kejahatan, atau pihak-pihak yang dapat dipandang sebagai wakil korban.

4. Siaran rekonstruksi yang memperlihatkan modus kejahatan secara eksplisit dan rinci dilarang.
5. Adegan rekonstruksi yang memperlihatkan cara pembatan alat-alat kejahatan tidak boleh disiarkan.(KPI, 2012)

\section{Persepsi}

Persepsi menurut Rakhmat merupakan pengalaman tentang objek, peristiwa, atau hubungan-hubungan yang diperoleh dengan menyimpulkan informasi dan menafsirkan pesan.(Heriyanto, 2014)

Sedangkan menurut Walgito, Persepsi merupakan suatu proses yang didahului penginderaan yaitu proses stimulus oleh individu melalui proses sensoris. Namun proses itu tidak berhenti begitu saja, melainkan stimulus tersebut diteruskan dan diproses selanjutnya merupakan proses persepsi. (Heriyanto, 2014)

Setiadi mengatakan bahwa Persepsi adalah suatu titik tolak pemikiran yang tersusun dari seperangkat kata-kata yang digunakan untuk memahami kejadian atau gejala dalam kehidupan.(Hakim, Mukmin, \& Sanusi, 2016)

\section{Penonton}

Cangara (Kurniawan, 2016) menyampaikan bahwa, "secara harafiah audiens disebut juga sebagai khalayak. Audiens adalah sekumpulan orang yang menjadi pembaca, pendengar, dan pemirsa di berbagai media atau komponen beserta isinya, seperti pendengar radio atau penonton televisi. Kata audiens sendiri lebih dikenal oleh masyarakat luas sebagai "receivers". Audiens atau khalayak adalah salah satu aktor dari proses komunikasi. Karena itu unsur khalayak tidak boleh diabaikan, sebab berhasil tidaknya proses komunikasi sangat ditentukan oleh khalayak". Menurut Nightingale (Kurniawan, 2016) ada 4 (empat) pengertiaan audiens, yaitu:

1. Audiens yaitu "orang-orang yang berkumpul".

2. Audiens yaitu " orang-orang yang dituju", berarti suatu goup yang terdiri dari orang-orang yang dikirim pesan.

3. Audies yaitu "yang terjadinya". Pengalaman akan menerima pesan, apakah sendiri atau dengan orang lain sebagai interaksi di kehidupannya.

4. Audiens yaitu "mendengar" atau "audisi".

\section{Komunikasi Massa}

Cangara (Kurniawan, 2016) menyatakan bahwa "Komunikasi merupakan proses 
penyampaian suatu pesan kepada orang lain dengan tujuan dapat membuat orang tersebut memberikan respon sesuai dengan keinginan si penyampai pesan. Istilah komunikasi berpangkal pada perkataan latin komunis yang artinya membuat kebersamaan antara dua orang atau lebih. Komunikasi juga berasal dari akar kata dalam latin communico yang artinya membagi".

Menurut Gebner (Ardianto, 2014), "Mass communications is the technologically and institutionally based production and distribution of the most broadly shared continuous flow of massage in industrial societies.(Komunikasi massa adalah produksi dan distribusi yang berlandaskan tekhnologi dan lembaga dari arus pesan yang kontinyu serta paling luas dimiliki orang dalam masyarakat industri “. .

\section{METODE PENELITIAN}

Peneliti menggunakan metode penelitian dengan pendekatan kualitatif deskriptif, dimana penulis menitikberatkan pada observasi tidak langsung dengan menggunakan metode studi kasus dan memberikan penafsiran terhadap hasilnya.

Proses Penelitian ini membahas secara mendalam mengenai fenomena-fenmena, opini, perilaku, sikap dan tanggapan dari masyarakat terhadap penanyangan reka ulang adegan kriminalitas khususnya pada program "Rekonstruksi Trans7".

Metode pengumpulan data yang digunakan pada penelitian ini adalah observasi nonpartisipan, wawancara dan studi kasus digunakan dengan tujuan untuk menjelaskan sedalam-dalamnya mengenai data yang didaptkan dari objek penelitian (kualitas) dan bukan banyaknya data (kuantitas).

Deskripsi detail dari topik yang diteliti dipaparkan secara sistematis, faktual dan akurat tentang fakta-fakta dan sifat-sifat populasi atau objek tertentu. Kemudian peneliti mengamati serta meninterpretasikan persepsi-persepsi tersebut, yang kemudian ditarik kesimpulan berdasarkan studi kasus mengenai penayangan reka ulang adegan kriminalitas pada program Rekonstruksi Trans7 dalam pandangan masyarakat.

Selain guna melengkapi kesimpulan, tekhnik wawancara dengan beberapa narasumber juga dilakukan, diantaranya Iwan Heriyanto sebagai Key Informan, dan sebagai informan yang merupakan penonton dari acara program "Rekonstruksi Trans7", Rani Cahya Agustin, Inggrid Maha Putri, Hasan Faiz.

Hasil akhir dari penelitian ini diharapkan dapat membuka lebih luas lagi sudut pandang masyarakat terhadap program reka ulang adegan kriminalitas pada program acara "Rekonstruksi" yang dutayangkan oleh stasiun televisi Trans7.Tidak hanya sebagai penambah informasi tetapi lebih kepada edukasi positif agar kedepannya masyarakat dapat lebih perduli terhadap keamanan lingkungan sekitar dan cepat tanggap jika ada kejadian yang sekiranya mencurigakan. Selain itu dengan munculnya pro dan kontra dari masyarakat diharapkan program acara Rekonstruksi Trans7 kembali memilah adegan yang layak untuk disiarkan ataupun tidak, karena tidak semua masyarakat dapat menangkap informasi tersebut menjadi edukasi yang bermanfaat.

\section{PEMBAHASAN}

Salah satu tayangan reka ulang kriminalitas yang hingga saat ini masih memiliki banyak penonton adalah "Rekonstruksi" yang disiarkan oleh stasiun televisi Trans7 setiap harinya. Berdasarkan dari segi penayangan, Trans7 menayangkan pada pukul 21.30, sedangkan pada Pedoman Perilaku Penyiaran telah diatur untuk penayangan yang menyiarkan kekerasan sebagai berikut "Program atau promo program yang mengandung muatan kekerasan secara dominan, atau mengandung adegan kekerasan eksplisit dan vulgar, hanya dapat disiarkan pada jam tayang dimana anak-anak pada umumnya diperkirakan sudah tidak menonton televisi, yakni 22.00 - 04.00 waktu setempat". (KPI, 2012)

Bila melihat jam tayang acara "Rekonstruksi" yang disiarkan Trans7 tidak sesuai dengan ketentuan yang diatur oleh KPI. Pada waktu 21.30 masih banyak penonton anak-anak yang menonton televisi atau sekedar mengerjakan hal lainnya dengan kondisi televisi yang menyala. Sehingga ada kemungkinan mereka menonton tayangan tersebut karena terdorong rasa ingin tahu yang tinggi dan secara kebetulan juga waktu penayangan masih belum terlalu larut malam.

Dari segi penayangan setiap adegan, "Rekonstruksi" terlalu santai dengan menayangkan reka ulang adegan, baik dari 
segi tindakan maupun backgroud musiknya. Hal ini membuat tayangan menjadi lebih seru, mencekam dan mengulik rasa ingin tahu masyarakat untuk menonton hingga selesai program acara tersebut.

Selain itu, tindakan reka ulang yang digambarkan dan dipertegas dengan penjelasan dari pengisi suara membuat tayangan "Rekonstruksi" menjadi lebih hidup dan detail dalam hal menjelaskan setiap tindakan kriminalitas yang telah dilakukan oleh tersangka. Hal ini dapat mengakibatkan muncul dan tumbuhnya tindakan seseorang untuk mengikuti, mencontoh atau bahkan mengembangkan tindakan-tindakan kriminalitas yang sudah pernah ia totonton sebelumnya. Sehingga pada akhirnya media televisi sebagai pemberi kontribusi paling besar dalam memberikan banyak informasi dan pembelajaran mengenai tindakan kriminalitas.

Sebelum membahas tentang persepsi dari masyarakat, penulis akan melihat ketentuan dari KPI tentang peraturan program rekonstruksi dengan program acara Rekonstruksi Trans7, yaitu;

Ketika lembaga penyiaran harus menyajikan berita atau dokumenter yang didasarkan pada reka ulang (rekonstruksi) dari peristiwa yang sesungguhnya terjadi, rekonstruksi tersebut harus disampaikan dengan :

1. Menjelaskan kepada khalayak sejaumana kesesuaian dan kekuatan materi dengan peristiwa sebenarnya apakah dibuat berdasarkan interpretasi bebas tentang peristiwa yang terjadi atau setiap detail penggambaran yang ditampilkan benarbenar akurat atau persis dengan peristiwa aslinya.

Pada setiap penayangan program acara Rekonstruksi Trans7 telah dibuat sesuai dengan hasil kronologis kejadian, dimana adegan-adegan yang ditampilkan selalu disisipi dengan penyampaian dari pihak kepolisian yang menangani kasus tersebut, dan juga diberikan sisipan tayangan yang sesuai tanggal dan waktu kejadian tersebut. Sehingga pada program tersebut dapat dengan jelas memberikan gambaran sejaumana kesesuaian dan kekuatan materi dengan peristiwa sebenarnya kepada khalayak dan dibuat berdasarkan interpretasi tentang peristiwa yang terjadi atau dalam arti kejadian pada setiap adegan-adegan tersebut secara rinci dan persis dengan peristiwa yang sebenarnya.

2. Tidak boleh ada perubahan atau penyimpangan terhadap fakta yang dapat menimbulkan intreprestasi yang salah atau tidak adil terhadap pihak yang memiliki kepentingan langsung terhadap isi program.

Pada setiap episode yang telah penulis teliti, program Rekonstruksi Trans7 tidak menyimpang dari fakta yang sebenarnya, karena penulis telah membandingkan pada setiap episodenya dengan pemberitaan kejadian yang ditayangkan tersbut dan hasilnya adalah sama dengan kronologis yang ada, seperti pada episode "Sepupuku Nerakaku" tayang 25 Januari 2019, sesuai dengan artikel atau pemebritaan yang ada pada Berita Pos Kupang yang berjudul "Kronologis Ketua RT Bunuh Selingkuhan Istri: Sakit Hati, Istri Pilih Tinggal Bersama Selingkuhannya" yang terbit pada tanggal 7 Januari 2019.(Rote, 2019)

3. Lembaga penyiaran harus memberitahukan dengan jelas asal versi reka ulang atau ilustrasi tersebut. Satsiun televisi dapat mencantumkan di layar, dan stasiun radio dapat melakukannya dengan memberitahu di awal, atau akhir program.

Stasiun Trans7 pada programnya ini telah memberitahukan dengan jelas dengan cara mencantumkan di layar di awal dan akhir juga diucapkan oleh pengantar acara atau penyiar dari acara tersebut asal reka ulang dan kronologis kejadian tersbut di awal dan akhir dari setiap episodenya.

4. Lembaga penyiaran tidak boleh merugikan pihak-pihak yang menjadi subjek dan objek reka ulang.

Untuk menjawab pada point ini sampai dengan penulis melakukan penelitian tidak adanya pihak-pihak yang menggugat atau merasa dirugikan dengan acara program Rekonstruksi Trans7 ini.

Dalam acara Rekonstruksi Trans7, apabila mengacu pada Pedoman Perilaku Penyiaran pun telah diatur tentang penyiaran Rekonstruksi kejahatan, maka dapat dilihat bagaimana program tersebut dalam menyiarkan adegan-adegan sesuai dengan ketetapan, yaitu;

1. Adegan rekonstruksi kejahatan yang eksplisit dan rinci tidak boleh disiarkan 
2. Pada acara Rekonstruksi Trans7, tidak menyiarkan suatu rekonstruksi secara rinci dan jelas penggambarannya, sekalipun disiarkan dengan menggunakan simulasi atau reka adegan dari, akan tetapi tidak berdasarkan suatu kejahatan yang jelasjelas gamblang, rinci dan jelas. Seperti halnya pada salah satu episode Rekonstruksi Trans7, "Sepupuku Nerakaku" tayang 25 Januari 2019 disimulasikan bagaimana pembunuhan tersebut dilakukan oleh pelaku.

3. Adegan rekonstruksi kejahatan seksual dan pemerkosaan sama sekali tidak boleh disiarkan.

Dalam acara Rekonstruksi Trans7, pada adegan kejahatan seksual atau pemerkosaan tidak disiarkan secara jelas atau nyata. Hanya saja menggambarkan bagaimana kejadian dalam kejahatan seksual atau pemerkosaan dapat terjadi dan dilakukan oleh pelaku.

4. Siaran rekonstruksi kejahatan harus memperoleh ijin dari korban kejahatan, atau pihak-pihak yang dapat dipandang sebagai wakil korban.

Pada Acara Rekonstruksi Trans7, dapat penulis sampaikan bahwa pada setian episode selalu memberkan pernyataan secara langsung yang berkatian dengan pihak-pihak yang merupakan wakil dari keluarga korban, sehingga dapat disimpulkan acara tersebut telah mendapatkan ijin dari pihak keluarga korban.

5. Siaran rekonstruksi yang memperlihatkan modus kejahatan secara eksplisit dan rinci dilarang.

Pada point ini, penulis melihat bahwa modus kejahatan secara eksplisit/gamblang/nyata digambarkan pada setiap episode Rekonstruksi Trans7. Modus kejahatan disini dapat terlihat dari awal penayangan sampai dengan akhir penayangan, dimana menggambarkan secara jelas modus kejahatan dari seorang pelaku pada saat melakukan aksinya.

6. Adegan rekonstruksi yang memperlihatkan cara pembatan alat-alat kejahatan tidak boleh disiarkan.

Pada saat penayangan acara Rekonstruksi Trans7 hanya memberikan gambaran sepintas saja bagaimana alat-alat yang digunakan untuk melakukan kejahatan.
Pada penelitian ini, Penulis mencoba melakukan beberapa wawancara dengan beberapa anggota masyarakat yang merupakan audience dari program acara Rekonstruksi Trans7, seperti halnya pihak Kepolisian khusus dalam bidang kriminalitas, pendapat dari ahli kejiwaan atau psikolog serta mahasiswa dan karyawan.

Berikut ini beberapa data yang telah Penulis lakukan:

\section{Key Informan}

Salau satu tim Bareskrim Polres Jakarta Selatan, yakni Bripka Iwan Heriyanto, berpendapat bahwa motif dari penayangan reka ulang adegan kriminalitas di televisi pada awalnya adalah sebagai sarana informasi informasi bagi masyarakat bahwa kejahatan saat ini sudah beragam dan dapat mengancam siapa saja, kapan saja dan dimana saja. Penayangan reka ulang adegan kriminalitas hanya semata adegan-adegan yang dipertontonkan bagi masyarakat agar masyarakat tetap waspada dan dapat menghindar dari tindakan kejahatan serupa. Adegan yang berisi kriminalitas atau adegan yang mengandung tindakan kekerasan hanya ditayangkan tidak lebih dari 5 shoot atau tayangan, selebihnya berisikan drama atau kronologis awal sebelum tindakan kriminalitas terjadi.

Selanjutnya, Bripka Iwan juga menyatakan bahwa sebenarnya penting bagi masyarakat untuk mengetahui reka ulang adegan kriminalitas yang mungkin terjadi di lingkungan tempat tinggal mereka, hal ini untuk mengantisipasi dan menjaga jikalau tindakan sebelum kriminalitas tersebut terjadi di masyarakat maka mereka akan lebih tahu terlebih dahulu, mereka dapat menghindari atau mengawasi lingkungan sekitar dari bahaya. Hanya saja beberapa masyarakat menilai tayangan reka ulang adegan kriminalitas bersifat kekerasan dan tidak layak untuk di tonton, terlebih bagi para remaja dan anak-anak.

Sebagai salah sati tom penindak kriminalitas, Bripka Iwan menganjurkan bagi masyarakat untuk tetap waspada dan menjaga lingkungan sekitar dengan cara melakukan pengecekan bagi para tamu yang hendak melakukan kunjungan ke rumah-rumah, mengecek kembali anggota keluarga yang masih belum pulang ke rumah jika sudah larut, melakukan pengecekan pada kunci rumah atau jendela 
menjelang tidur, menjadi pribadi yang baik di perkumpulan masyarakat dan masih banyak lagi lainnya.

\section{Informan 1.}

Merupakan seorang Psikolog yang berdomisili di Jakarta Selatan berpendapat bahawa bila dilihat dari jam tayang sudah sesuai dengan jam tayang seharusnya, yaitu malam hari pukul 21.30 WIB mengingat terdapat beberapa adegan dalam tayangan tersebut yang tidak sepantasnya dilihat oleh anak-anak. Program acara tersebut menurutnya tidak terlalu vulgar karena tidak memperlihatkan secara jelas dan detail adegan-adegan yang dimaksudkan. Sisi positif yang dapat diambil dari program acara Rekonstruksi Trans7 ini menurutnya adalah sebagai peringatan terhadap masyarakat bahwa kejahatan dapat terjadi kapan saja, dimana saja, dan juga dapat terjadi pada siapa saja, sehingga dapat menjadi pengetahuan untuk mencegah terjadinya hal-hal yang tidak diinginkan di sekitar kita.

Sedangkan sisi negatif dari program acara tersebut menurut Faiz, yaitu dapat dijadikan referensi juga bagi sebagian orang untuk melakukan tindak kejahatan, meskipun telah ditayangkan pada jam tayang di malam hari dengan tujuan untuk ditonton oleh orang dewasa, namun perlu diperhatikan kembali bahwa tidak semua orang dewasa memiliki pemikiran yang dewasa pula untuk memilahmilah mana yang baik dan tidak. Sebagian orang dewasa memiliki regulasi emosi yang kurang baik, sehingga ketika orang tersebut kurang dapat mengendalikan emosinya, mereka berpotensi bertindak sesuai dengan emosinya, mereka berpotensi bertindak sesuai dengan emosi yang sedang dirasakannya.

Menurutnya pula, dengan adanya acara tersebut dapat meningkatkan terjadinya kriminalitas di masyarakat, karena sisi negatif yang telah dijabarkan sebelumnya. Namun disaat yang bersamaan acara tersebut dapat meningkatkan kesadaran masyarakat untuk lebih waspada terhadap terjadinya kriminalitas disekitar mereka.

Saran diberikan oleh Faiz adalah agar acara Rekonstruksi Trans7 ditayangkan lebih malam, karena mengingat masih banyak anakanak dan remaja yang menonton televisi pada jam tersebut.

\section{Informan 2}

Inggrid Mahaputri merupakan mahasiswa Teknik salah satu perguruan tinggi di Bogor serta berdomisili di Bogor menyatakan bahwa Acara Rekonstruksi Trans7 alangakah sebaiknya tidak perlu ditayangkan di televisi, cukup dilakukan oleh pihak yang berwajib saja. Karena apabila yang menonton tidak cukup umur dapat menimbulkan salah pemahaman dari acara tersbut.

Namun demikian Inggrid menyatakan bahwa acara tersebut tidak vulgar, baik dalam adegan kekerasan dan seksualitasnya.

Sisi positif dari acara Rekonstruksi Trans7 menurutnya adalah penonton dapat mengambil hikmah dari segala sesuatu peristiwa/ kejadian yang ada di acara tersebut dan berwaspada selalu akan segala hal.

Menurutnya pula, untuk sisi negatif pada acara tersebut tidak ada, hanya saja untuk jam tayangnya saja yang perlu diperhatikan.

Inggrid pun menambahkan bahwa sebetulnya bila dikatakan akan meningkatkan kriminalitas, semua tergantung kepada masyarakat yang menonton acara tersebut bagaimana mereka dapat lebih bijaksana dalam menonton dan menanggapi acara terebut agar tidak meningkatkan kriminalitas dan tidak menjadikan trend di kalangan masyarakat akan pembunuhan dan lain-lain.

Sedangkan untuk sarannya, Inggrin menambahkan perlunya diperhatikan jam tayang serta adegan-adegan yang dekiranya pantas untuk ditayangkan di televisi.

\section{Informan 3}

Rani Cahya Agustin yang merupakan seorang karyawan swasta yang berdomisili di Depok menyatakan bahwa acara Rekonstruksi Trans7 merupakan acara yang bagus dan dapat memberikan suatu kewaspadaan terhadap diri sendiri.

Rani pun menambahkan bahwa acara tersebut menayangkan adegan yang dapat dikatakan tidak terlalu vulgar bila dilihat dari adegan kekerasannya dan adegan seksualitasnya.

Untuk sisi positifnya dari acara tersebut, Rani menyatakan bahwa masyarakat sebagai penonton dapat berhati-hati dalam segala bentuk kejahatan dimanapun dan kapanpun.

Sedangkan untuk sisi negatif dari acara tersebut, Rani menyatakan acara tersebut dapat ditiru oleh sebagian penonton yang mempunyai kepentingan dan pemikiran yang berbeda setelah melihat modus dan agedan kekerasan yang ditampilkan pada acara tersebut. 
Serta saran yang diberikannya adalah acara tersebut tidak perlu detail pada adegan-adegan bagaimana kronologis kejadiannya.

\section{PENUTUP}

Semakin beragamnya tayangan di televisi saat ini telah menjadikan masyarakat sebagai individu yang selektif dan memilah tayangan yang mereka butuhkan atau sesuai dengan apa yang hendak mereka tonton. Tetapi masih banyak masyarakat yang menilai bahwa tayangan yang memberikan gambaran detail mengenai sebuah kasus adalah tayangan yang menarik untuk ditonton, hal ini disebabkan rasa ingin tahu yang tinggi dan dorongan emosi yang semakin meningkat apabila menyaksikan tayangan tersebut.

Apabila melihat dari ketentuan yang diberikan oleh KPI akan penayangan program reka ulang adegan kriminalitas, beberapa point terpenuhi dan sesuai dengan ketentuan dari KPI, hanya jam tayang yang kurang sesuai dengan ketentuan KPI yaitu ditayangkan pada pukul 21.30 sedangkan KPI menentukan jam tayang untuk acara kriminalitas pada pukul $22.00-04.00$ waktu setempat.

Kemudian untuk ketentuan KPI bahwa Siaran rekonstruksi yang memperlihatkan modus kejahatan secara eksplisit dan rinci dilarang, tetapi pada acara rekonstruksi Trans7 penulis melihat bahwa modus kejahatan secara eksplisit/gamblang/nyata digambarkan pada setiap episodenya. Modus kejahatan disini dapat terlihat dari awal penayangan sampai dengan akhir penayangan, dimana menggambarkan bagaimana modus kejahatan dari seorang pelaku pembunuhan dalam melakukan aksinya.

Pada tayangan reka ulang adegan krminalitas yang disiarkan oleh Trans7, yairu Rekonsruksi secara tidak langsung dapat memberikan dampak psikologis massa yang sangat luas, hal ini dikarenakan program tersebut ditayangkan setiap hari dan dengan menampilkan beragam modus dari setiap kronologis yang diceritakan secara jelas dan menayangkannya dengan nuansa yang dapat dengan mudah dipahami oleh masyarakat.

Program acara Rekonstruksi Trans7 dapat disimpulkan dapat dijadikan sebuah acara yang memeberikan pembelajaran kepada pemirsa akan tingkat kewaspadaan masyarakat terhadap kejahatan.

Tetapi acara tersebut pula bagi sebagian masyarakat dapat dijadikan sebagai modus kejahatan yang dapat ditiru oleh sebagian orang yang tidak dapat mengendalikan emosinya, karena dalam acara ini memberikan gambaran yang lengkap mengenai kronologis dari seluruh kasus kriminalitas sehingga masyarakat yang menonton dan memiliki niat tidak baik akan dengan mudah meniru dan bahkan mengembangkan tindakan kriminalitas tersebut pada tingkatan yang lebih tidak manusiawi.

Oleh karena itulah dibutuhkannya peraturan penyiaran yang tegas dan teratur agar tayangan tersebut tidak dijadikan sebagai sebuah sekuel drama kriminalitas, tetapi hanya disiarkan dalam pemberitaan kriminalitas saja.

\section{REFERENSI}

aparti.com. (2019). Arti Kata Rekonstruksi Makna Pengertian Dan Definisi Apaarti.com. Retrieved February 17, 2019, from

https://www.apaarti.com/rekonstruksi.ht $\mathrm{ml}$

Ardianto, E. (2014). Komunikasi Massa; Suatu Pengantar (Revisi). Bandung: Simbiosa Rekatama Media.

Esti, L., \& Hartanti, P. (2015). Kebijakan Media Televisi Di Era Media Baru. Jurnal Interact, 4(1), 37-46. Retrieved from

http://ojs.atmajaya.ac.id/index.php/fiabik om/article/download/730/590

Ferry. (2014). Media Televisi Kajian Peran Media Massa dan Pengaruhnya bagi Remaja. Peran Media Massa, 14(1), 12. Retrieved from http://dinus.ac.id/repository/docs/ajar/art icle5

Hakim, J., Mukmin, Z., \& Sanusi, S. (2016). PERSEPSI MASYARAKAT TERHADAP KEBIJAKAN PEMERINTAH KOTA BANDA ACEH TENTANG PEMBERLAKUAN JAM MALAM BAGI PEREMPUAN (Studi Kasus di Kecamatan Baiturrahman Kota Banda Aceh). Jurnal Ilmiah Mahasiswa Pendidikan Kewarganegaraan, 1(1).

Retrieved from http://www.jim.unsyiah.ac.id/pendidikan -kewarganegaraan/article/view/478

Heriyanto. (2014). PERSEPSI MASYARAKAT TERHADAP KUALITAS PELAYANAN PUBLIK PADA BAGIAN ADMINISTRASI KESEJAHTERAAN 
RAKYAT PEMERINTAH KABUPATEN

GUNUNGKIDUL DIY. Universitas

Negeri Yogyakarta. Retrieved from

http://eprints.uny.ac.id/15252/1/merged.

pdf

KPI. (2012). Pedoman perilaku penyiaran.

Retrieved February 6, 2019, from

http://www.radioprssni.com/prssninew/i

nternallink/legal/Pedoman Perilaku revisi.htm

Kurniawan, A. (2016). KARAKTERISTIK

DAN RESPON AUDIENS PENONTON

TAYANGAN SINETRON TUKANG

BUBUR NAIK HAJI THE SERIES.

Lampung. Retrieved from

http://digilib.unila.ac.id/24164/3/SKRIP

SI TANPA BAB PEMBAHASAN.pdf

Morisan. (2010). Manajemen Public

Relations: Strategi Menjadi Humas

Profesional. Jakarta: Prenada Media

Group.

Rote, E. (2019). Kronologis Ketua RT Bunuh Selingkuhan Istri: Sakit Hati, Istri Pilih Tinggal Bersama Selingkuhannya - Pos Kupang. Retrieved February 15, 2019, from

http://kupang.tribunnews.com/2019/01/0 7/kronologis-ketua-rt-bunuhselingkuhan-istri-sakit-hati-istri-pilihtinggal-bersama-selingkuhannya

Supriana, H. (2017). PENGARUH MEDIA MASSA TERHADAP CITRA PARTAI POLITIK. Lampung. Retrieved from http://repository.radenintan.ac.id/3055/1/ SKRIPSI LENGKAP HERRI.pdf

TRANS7 | Rekonstruksi. (n.d.). Retrieved February 6, 2019, from https://www.trans7.co.id/programs/rekon struksi

\section{BIODATA PENULIS}

Susilowati, S.Sos, MM. Lahir di Jakarta, 21 Desember 1986. Profesi sebagai dosen Fakultas Komunikasi dan Bahasa Universitas BSI Jakarta, yang beralamat di BSI Pemuda, Jalan Kayu Jati 5, Rawamangun, Jakarta Timur.

Devy Putri Kussanti, S.Sos, M.Si. Lahir di Jakarta, 13 Desember 1983. Profesi sebagai dosen Fakultas Komunikasi dan Bahasa Universitas BSI Jakarta, yang beralamat di BSI Pemuda, Jalan Kayu Jati 5, Rawamangun, Jakarta

Timur. 